\title{
Study on the combined threshold for gully-type debris flow early warning
}

\author{
Jian Huang ${ }^{1}$, Theodoor Wouterus Johannes van Asch ${ }^{1,2}$, Changming Wang ${ }^{1}$, and Qiao Li ${ }^{1}$ \\ ${ }^{1}$ State Key Laboratory of Geohazard Prevention and Geoenvironment Protection Chengdu University of Technology, \\ Chengdu, Sichuan 610059, China \\ ${ }^{2}$ Faculty of Geosciences, Utrecht University, Heidelberglaan 2, 3584, CS, the Netherlands
}

Correspondence: Jian Huang (huangjian2010@gmail.com)

Received: 13 August 2018 - Discussion started: 31 August 2018

Revised: 9 December 2018 - Accepted: 13 December 2018 - Published: 9 January 2019

\begin{abstract}
Gully-type debris flow induced by high-intensity and short-duration rainfall frequently causes great loss of properties and causalities in mountainous regions of southwest China. In order to reduce the risk by geohazards, early warning systems have been provided. A triggering index can be detected in an early stage by the monitoring of rainfall and the changes in physical properties of the deposited materials along debris flow channels. Based on the method of critical pore pressure for slope stability analysis, this study presents critical pore pressure threshold in combination with rainfall factors for gully-type debris flow early warning. The Wenjia gully, which contains an enormous amount of loose material, was selected as a case study to reveal the relationship between the rainfall and pore pressure by field monitoring data. A three-level early warning system (zero, attention, and warning) is adopted and the corresponding judgement conditions are defined in real time. Based on this threshold, there are several rainfall events in recent years have been validated in Wenjia gully, which prove that such a combined threshold may be a reliable approach for the early warning of gullytype debris flow to safeguard the population in the mountainous areas.
\end{abstract}

\section{Introduction}

Gully-type debris flow, a kind of common geohazard in southwest China, is mainly triggered by high-intensity shortduration rainfall causing a runoff-induced effect. Most of them are initiated by shallow landslides distributed along the gullies in mountainous regions (Kean et al., 2013). The fast growth of the population and economic development in these areas increase the frequency of catastrophic accidents and consequent socio-economic losses. The Wenchuan earthquake on 12 May 2008, Yushu earthquake on 14 April 2010, Lushan earthquake on 20 April 2013, Ludian earthquake on 3 August 2014, and the Nepal earthquake on 25 April 2015 triggered thousands of landslides and cracked mountains, which made these areas prone to debris flow development under rainstorm conditions (Shieh et al., 2009). In the ChiChi earthquake area in Taiwan, numerous co-seismic landslides were triggered as well, causing the continuous triggering of debris flows for 10 years after the earthquake (Yu et al., 2013b). These catastrophic events have greatly shocked the local people and government because of the human vulnerability to natural hazards as well as the lack of knowledge on natural disaster prevention and mitigation. There is an urgent demand for an effective method to reduce the hazard and risk. Therefore, researchers have been working on the forecast of debris flow occurrence and setting up of early warning systems for several decades. At the regional scale, the methods for shallow-landslide early warning are mostly based on statistical models and empirical conclusion and have already proven their importance in landslide prevention and mitigation (Keefer et al., 1987; Guzzetti et al., 2007a; Baum and Godt, 2009; Segoni et al., 2014; Shuin et al., 2012; Tropeano and Turconi, 2004). In the beginning, one or two parameters were selected for the assessment of rainfall thresholds to forecast landslide occurrence, e.g. rainfall intensity and duration (Keefer et al., 1987; Guzzetti et al., 2007a, b; Cannon et al., 2008), antecedent precipitation (Glade et al., 2000), and cumulative rainfall (Guo et al., 2013). Hereafter, Baum 
and Godt (2009) presented a combination threshold, including cumulative rainfall threshold, rainfall intensity-duration threshold, and antecedent water index or soil wetness for the shallow landslide forecasting. At the local scale, physical methods (e.g. numerical simulation) were used to find relationships among rainfall, soil properties, and pore pressure and their contributions to slope stability (Iverson, 1997; Peng et al., 2014; van Asch et al., 2013; Thiebes, 2012; Chae and Kim, 2011; Michel and Kobiyama, 2016; Beven and Kirkby, 1979; Deb and El-Kadi, 2009). However, detailed information related to landslide triggering is required to establish the site-specific thresholds, which are very difficult to extrapolate to other places due to the large variation in soil properties between different regions. Yu et al. (2013a) selected several identified factors related to topography, geology, and hydrology to develop a normalised critical rainfall factor combined with an effective cumulative precipitation and maximum hourly rainfall intensity index for the forecast of gully-type debris flows. The model, which is partly based on a runoff-induced mechanism, has been successfully applied to the Wangmo River catchment, Guizhou Province, China (Yu et al., 2014).

Unfortunately, strong earthquake shocks in southwest China caused a significant rise in the frequency of debris flow during recent years. The long-term effect of earthquakes causes the region to become a high-risk area, and particularly the gullies in mountains with no debris flows before become the debris flow gullies at present. The mechanism, movement characteristics, and thresholds of debris flow in these shocked areas, therefore, have been paid great attention by researchers, e.g. Guo et al. (2013), Huang et al. (2015a), Yin et al. (2010), Yu et al. (2014), Zhou and Tang (2013), and so on. But these models still mainly focused on rainfall threshold, with no consideration about the rise of loose deposited material and unstable slope distributed along the catchments. Therefore, during this study, pore pressure in slope stability analysis has been considered for establishing a combined threshold. The goal of the presented study is to propose a comprehensive method for gully-type debris flow early warning by real-time monitoring of rainfall and changes in pore pressure in the deposited material along channels in southwest China. The infinite slope stability analysis was applied to identify the critical stability conditions of the deposited material. Then, a comprehensive warning threshold for rainfall and critical pore pressure will be presented, which includes both rainfall conditions and soil properties. Finally, verification and revision will be discussed to search for a practical and useful method for reducing the risks of gullytype debris flow in southwest China.

\section{Study area}

The Wenjia gully is located to the north of Qingping town, Mianzhu city, Sichuan Province, southwest China, and has a

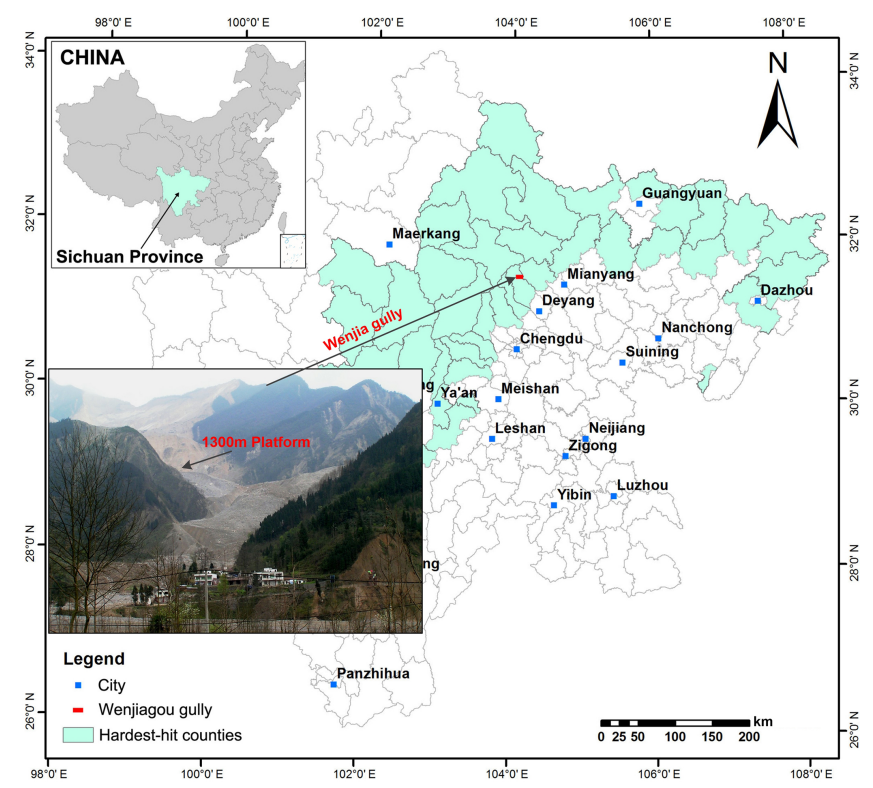

Figure 1. Location of Wenjia gully modified from Huang et al. (2013). The inset photograph of Wenjia gully at the left bottom was taken from the other side of Mianyuan River on $10 \mathrm{Au}-$ gust 2008 .

catchment area of $7.8 \mathrm{~km}^{2}$ and a $5.2 \mathrm{~km}$ long main channel, as shown in Fig. 1. The elevation of this study area ranges from $860 \mathrm{~m}$ to $2400 \mathrm{~m}$ a.s.l. (Fig. 2a), and the main valley with slope inclinations between 30 and $70^{\circ}$ has been deeply incised by the Mianyuan River. The average yearly temperature is about $16^{\circ} \mathrm{C}$, and the climate is mild semi-tropical and moist with abundant rainfall and four distinguishable seasons. A total of $80 \%$ of the rainfall is concentrated in 3 months from July to September.

Before the Wenchuan earthquake on 12 May 2008, the Wenjia catchment was covered by rich vegetation, and the channel was smooth and stable, as shown in Fig. 3a. At that time, few geological disasters had occurred in this region. Therefore, many farmers settled down at the foothills along the Mianyuan River at Qingping town downstream of the Wenjia channel's outlet (Fig. 3a, b). During the earthquake, a giant landslide occurred upstream in the catchment at the top of the watershed, which generated abundant co-seismic rockfall material and finer landslide deposits on a platform with an elevation of $1300 \mathrm{~m}$ a.s.l. (Fig. 1, the photograph at the left bottom of the main map). These loose solid erodible materials could easily transform into debris flows during a rainstorm. Shortly after the earthquake on 24 September 2008, one rainfall event caused the first debris flow in this gully. The catastrophic debris flow triggered by a heavy rainfall on 13 August 2010, with a peak discharge of $1530 \mathrm{~m}^{3} \mathrm{~s}^{-1}$ and a total volume of $4.5 \times 10^{6} \mathrm{~m}^{3}$, caused many victims and the burying of reconstructed houses and most of the downstream check dams along the channel (Yu et al., 2013b). 

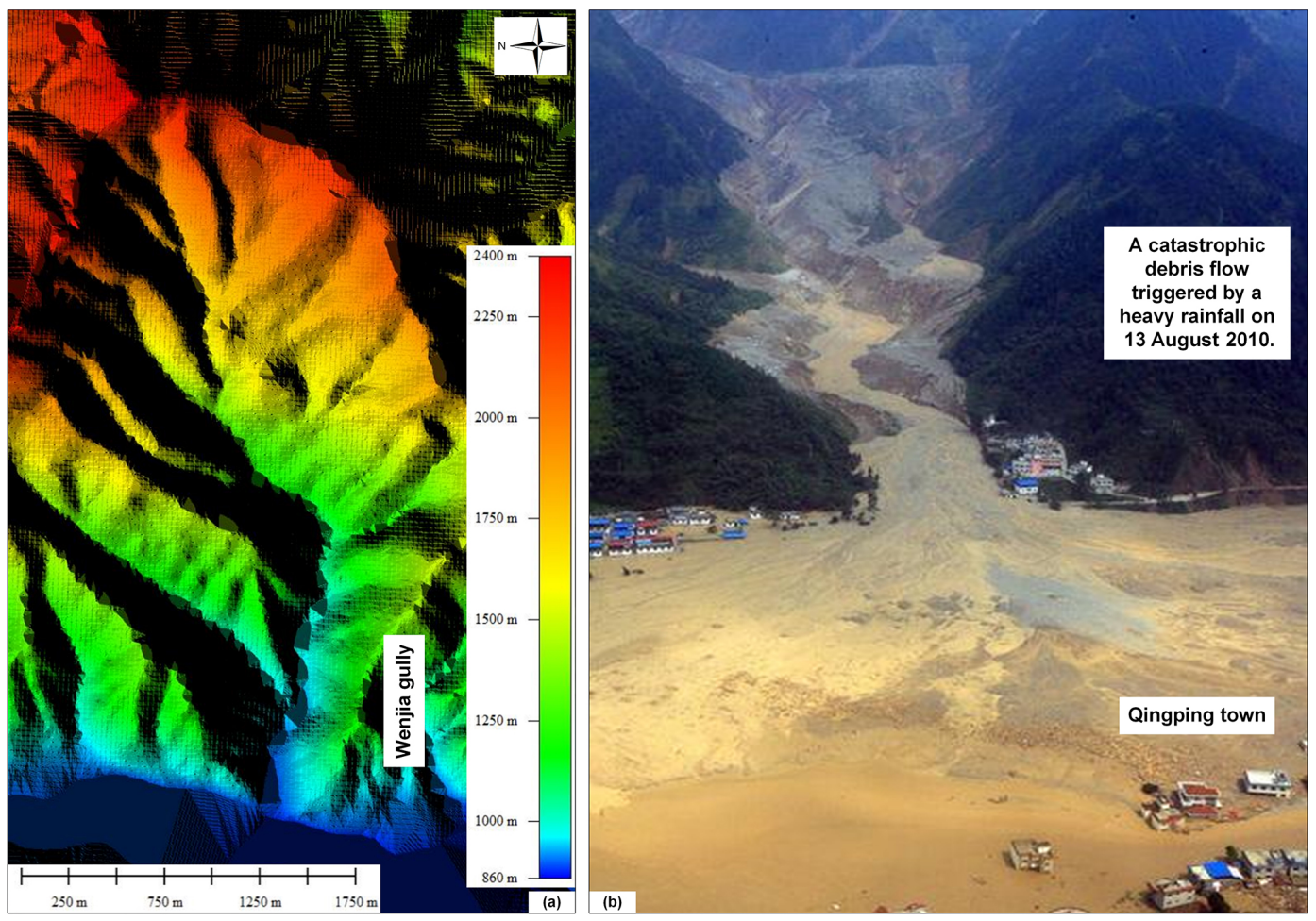

Figure 2. DEM map of Wenjia gully and photo of the debris flow event (13 August 2010).

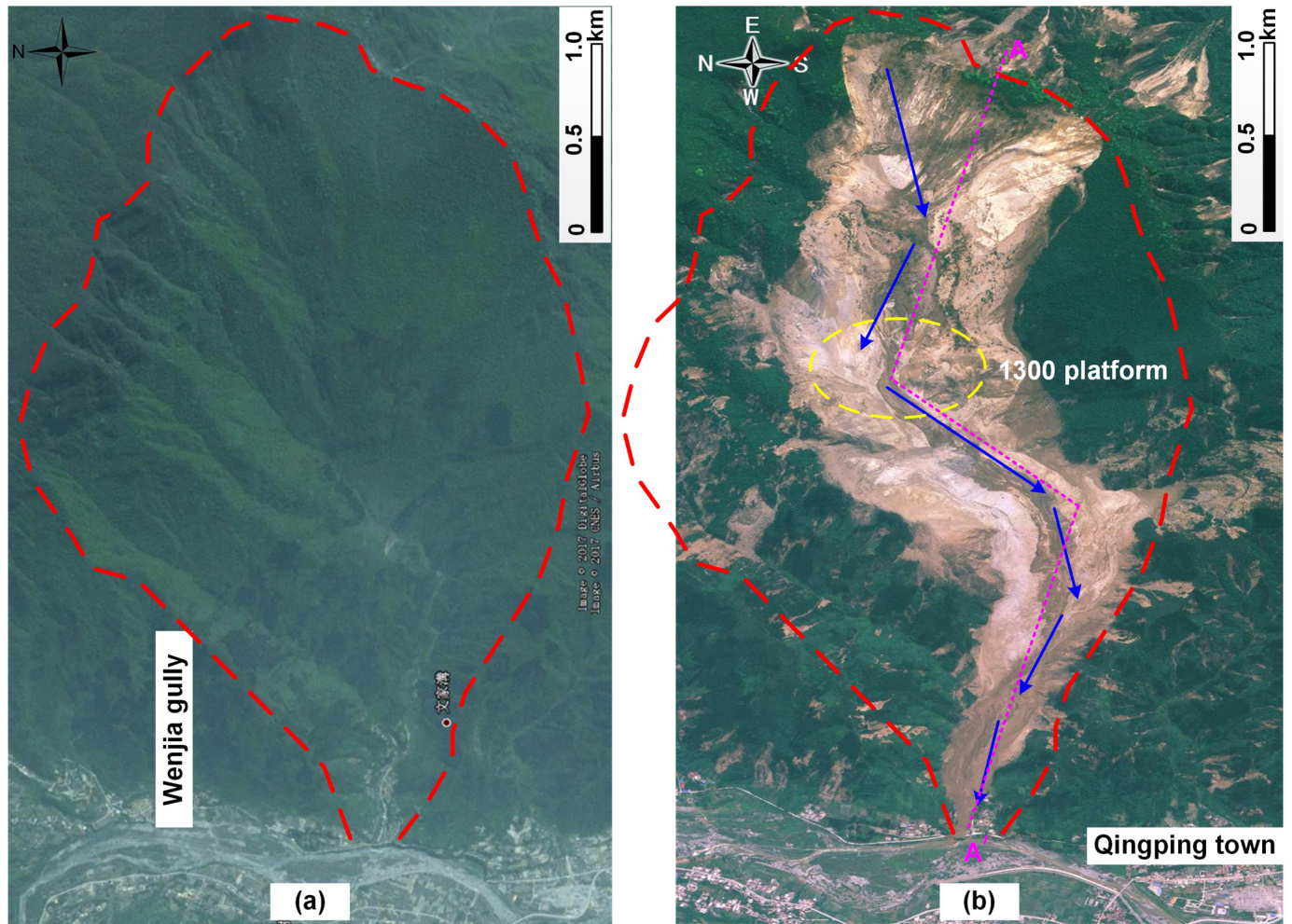

Figure 3. Aerial image of Wenjia gully (a) image from Google Earth on 31 December 2007; (b) aerial photograph taken on 18 May 2008. 


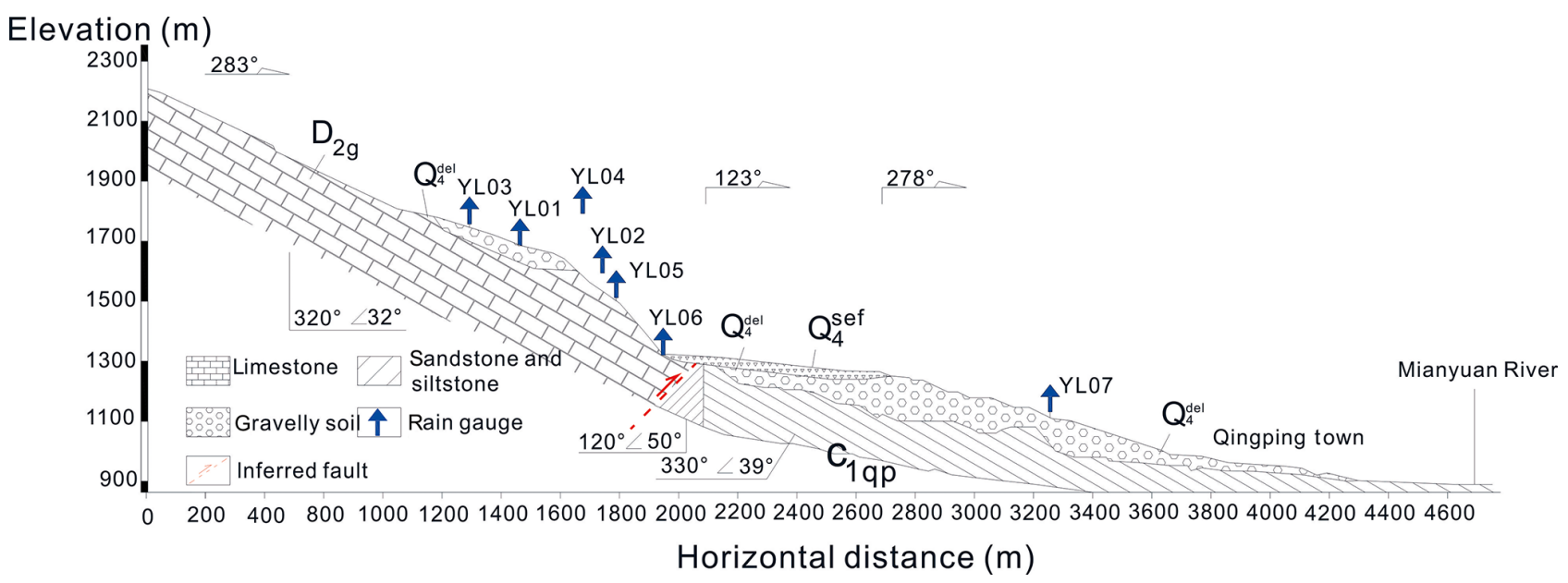

Figure 4. Geological profile of the main channel of Wenjia gully.

Figure 4 is the geological profile of cross section $\mathrm{A}-\mathrm{A}^{\prime}$ in Wenjia gully (Fig. 3b). The exposure strata are Guanwushan Group (upper Devonian period) with limestone and Qingping Group (Cambrian period) with sandstone and siltstone. Field investigation also shows that the main loose deposits are located at the 1300 platform (Figs. 1 and 3). During heavy rains, the intense surface run-off may cause the unstable slope collapse into the channel, bed failure, or run-off scouring of the loose deposited material. This explains why there would be giant debris flow occurrence in this gully, e.g. the debris flow event on 13 August 2010 mentioned above.

\section{Methodology}

According to Terzaghi theory in soil mechanics, the shear strength of material at a point within a slope can be expressed as Eq. (1).

$\tau=c+(\sigma-u) \tan \varphi$,

where $\tau$ is the shear strength of the slope material, $c$ is the effective cohesion of the material, $\varphi$ is the effective friction angle of the material, $\sigma$ is the total stress normal to a potential slip surface, and $u$ is the pore pressure. Generally, the strength parameters $(c, \varphi)$ of the slope material mainly determined the stability of the slope and the potential position of the slip surface.

Rainfall infiltrates into a hillslope, always accumulating in a saturated zone above a permeability barrier, and increases the pore pressures within the slope material. Based on the Terzaghi's work, the increase in $u$ would cause the effective overburden stress $(\sigma-u)$ to decrease and therefore the decrease in the shear strength until the slope fails. A formula to calculate the critical level of the pore pressure, for a highly idealised model of an infinite slope composed of cohesionless materials $(c=0)$, has been presented by Keefer et al. (1987), assuming both slip surfaces and piezometric surfaces are parallel to the ground surface. For all these assumptions, the critical pore pressure can be calculated by Eq. (2).

$u_{\mathrm{c}}=Z \times \gamma_{\mathrm{t}} \times\left(1-\frac{\tan \theta}{\tan \varphi}\right)$,

where $Z$ is the depth of slip surface, $\gamma_{\mathrm{t}}$ is the total unit weight of the slope material, and $\theta$ is the slope inclination; the other parameters are the same to those mentioned above.

Since the deposited material along the channel usually is loose and has a grain shape, it can be regarded as an infinite slope composed of cohesionless materials. Therefore, the critical pore pressure (Eq. 2) can be used to calculate the stability of the source area. Then pore pressure and rainfall monitoring sensors were installed in the Wenjia gully to capture the real-time data and put forward a comprehensive warning threshold for forecasting debris flow occurrence. The history events of rainfall with debris flow occurrences and non-occurrences have been collected for this study from 2008 to 2018. Fortunately, three debris flow events with detailed rainfall and pore pressure monitoring data have been recorded, which could be important evidence to prove the presented methodology.

\section{Results}

\subsection{Data analysis}

Data were collected from the literature about the occurrence of debris flows in the Wenjia gully and from technical reports and documents presented by government agencies. Since there is a large difference in debris flow frequency before and after the Wenchuan earthquake, only the data after the quake were used for the analyses and set-up of an early warning system (Table 1). There were no debris flow events after 2014, so the rainfall data are omitted in the table. 
Table 1. Primary rainfall events in the catchment of Wenjia gully (2008-2018), added from Xu (2010) and Yu et al. (2013b).

\begin{tabular}{|c|c|c|c|c|}
\hline Time & $\begin{array}{r}\text { Maximum hourly } \\
\text { rainfall intensity } \\
\left(I_{\mathrm{h}}: \mathrm{mm}\right)\end{array}$ & $\begin{array}{r}\text { Accumulated } \\
\text { precipitation } \\
\left(R_{\mathrm{d} t}: \mathrm{mm}\right)\end{array}$ & $\begin{array}{l}\text { Debris flow } \\
\text { occurrence } \\
\text { or not }\end{array}$ & $\begin{array}{r}\text { Volume of } \\
\text { debris flow } \\
\left(\mathrm{m}^{3}\right)\end{array}$ \\
\hline 24 Sep 2008 & 30.5 & 88.0 & Yes & $5.0 \times 10^{5}$ \\
\hline 18 Jul 2009 & 20.5 & 70.5 & No & - \\
\hline 25 Aug 2009 & 28.9 & 86.7 & No & - \\
\hline 13 Sep 2009 & 15.4 & 84.6 & No & - \\
\hline 27 May 2010 & 10.5 & 34.9 & No & - \\
\hline 13 Jun 2010 & 5.5 & 95.1 & No & - \\
\hline 25 Jul 2010 & 11.6 & 89.6 & No & - \\
\hline $31 \mathrm{Jul} 2010$ & 51.7 & 60.2 & Yes & $1.0-2.0 \times 10^{5}$ \\
\hline 13 Aug 2010 & 70.6 & 185.0 & Yes & $4.5 \times 10^{6}$ \\
\hline 19 Aug 2010 & 31.9 & 72.6 & Yes & $3.0 \times 10^{5}$ \\
\hline 18 Sep 2010 & 29.0 & 52.0 & Yes & $1.7 \times 10^{5}$ \\
\hline 22 Sep 2010 & 24.5 & 81.2 & No & - \\
\hline 2 May 2011 & 5.6 & 35.8 & No & - \\
\hline 5 Jul 2011 & 12.5 & 61.3 & No & - \\
\hline $21 \mathrm{Jul} 2011$ & 23.5 & 63.2 & No & - \\
\hline 30 Jul 2011 & 18.2 & 78.3 & No & - \\
\hline 16 Aug 2011 & 10.5 & 44.3 & No & - \\
\hline 21 Aug 2011 & 13.6 & 76.6 & No & - \\
\hline 7 Sep 2011 & 15.2 & 51.3 & No & - \\
\hline 27 Oct 2011 & 8.5 & 36.9 & No & - \\
\hline 21 Jul 2012 & 30.5 & 76 & No & - \\
\hline 14 Aug 2012 & 68 & 109 & Yes & $3.2 \times 10^{4}$ \\
\hline 17 Aug 2012 & 41 & 89.5 & Yes & $7.8 \times 10^{4}$ \\
\hline 18 Aug 2012 & 69 & 104.5 & No & - \\
\hline 16 Sep 2012 & 12 & 44 & No & - \\
\hline 25 Sep 2012 & 4.5 & 52 & No & - \\
\hline 19 Jun 2013 & 33.5 & 62 & No & - \\
\hline 29 Jun 2013 & 16.5 & 41.5 & No & - \\
\hline 30 Jun 2013 & 40.5 & 94 & No & - \\
\hline 4 Jul 2013 & 32 & 98 & No & - \\
\hline $8 \mathrm{Jul} 2013$ & 53 & 195 & Yes & $34.4 \times 10^{4}$ \\
\hline $10 \mathrm{Jul} 2014$ & 51.5 & 67 & No & - \\
\hline 8 Aug 2014 & 50.5 & 68.5 & No & - \\
\hline : & $\vdots$ & $\vdots$ & $\vdots$ & : \\
\hline
\end{tabular}

Table 1 and Fig. 5 show that the number of debris flows decreases with time. Several years after the earthquake, however, giant debris flows still caused catastrophic losses, which alarmed the public and government because of their huge destructive power and long-term impact. Particularly on $13 \mathrm{Au}$ gust 2010, a great rainstorm lasting for $2 \mathrm{~h}$ during the night, triggered a giant debris flow, which buried Qingping town in the Mianyuan River floodplain. According to the inventory report, the maximum deposition height was up to $6 \mathrm{~m}$. Most of the check dams located in the downstream part of the Wenjia gully collapsed and lost their effectiveness after passing of the debris flow. Meanwhile, it eroded the channel bottom over a depth of about $13 \mathrm{~m}$ (Yu et al., 2013b).

Pore pressure and rainfall monitoring sensors have been installed for understanding their relationship and the link with debris flow occurrence. The real-time monitoring system in the Wenjia gully includes seven automatic rain gauges and five pore pressure monitoring instruments. The installation was finished by 1 April 2012 (see Table 2, Figs. 4 and $6)$. It can be seen that all rain gauges are arranged in the upstream part of the Wenjia gully catchment, while pore pressure monitoring sensors are distributed along the main stream 


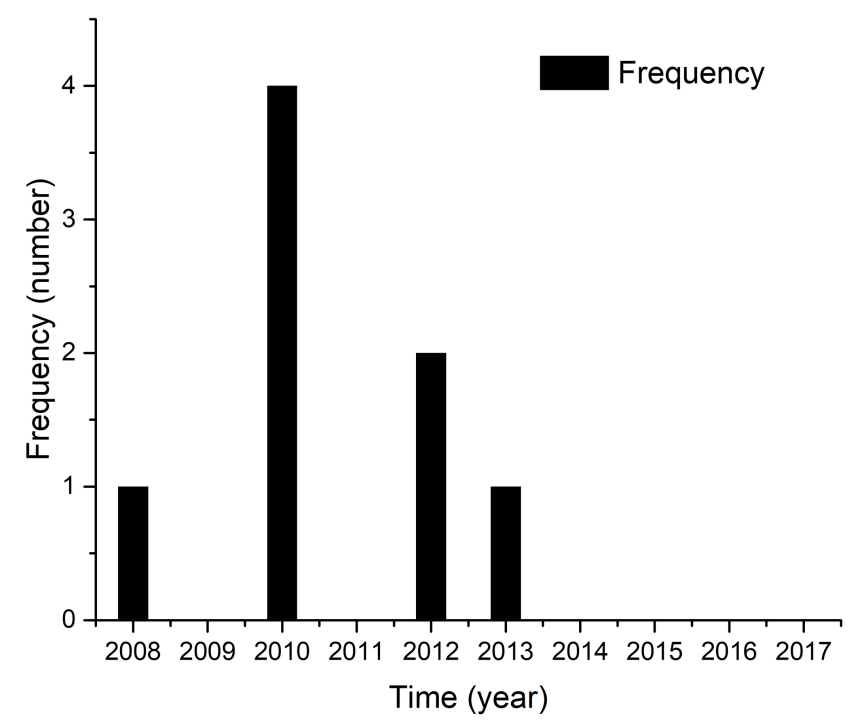

Figure 5. The frequency of debris flow events in Wenjia gully from 2008 to 2017.

of the Wenjia gully, with a depth of $1 \mathrm{~m}$ below the ground surface.

The 2012 heavy rainfall event on 14 August, which triggered a debris flow, was completely recorded by the real-time monitoring system. During the rainstorm, monitoring sensors YL05, YL06 and SY02, SY05 lost connection with the monitoring centre. The other monitoring sensors worked well, as shown in Figs. 7 and 8. The figures show that the rainfall was almost concentrated in $2 \mathrm{~h}$ from 17:00 until 19:00 UTC +8 . The amount of precipitation was highly variable along the channel of the Wenjia gully. The maximum hourly rainfall intensity is $73.5 \mathrm{~mm}$ (YL01, 17:00), and the cumulative maximum rainfall is $118 \mathrm{~mm}$ (YL04).

The maximum hourly rainfall and cumulative rainfall are not found in the highest part of the catchment. The variability in cumulative maximum rainfall is larger than the variability in maximum hourly rainfall intensity. Figure 8 shows the relation between hourly rainfall and pore pressure: the small amount of rain from 02:00 to 05:00 with a maximum hourly rainfall of $12.5 \mathrm{~mm}$ did not trigger any change in pore pressure. However, during the concentrated rain period between 15:00 and 18:00 there was a sudden rise in the pore pressure. The debris flow was triggered adjacently when it reached the maximum rise in the pore pressure. The highest value of the pore pressure is $9.1 \mathrm{kPa}(\mathrm{SY} 01)$ at $18: 00,5.7 \mathrm{kPa}(\mathrm{SY} 03)$ at 20:00, and 7.8 $\mathrm{kPa}$ (SY04) at 17:00. The sudden rise in pore pressure may therefore be a good indicator for contributing to the gully-type debris flow occurrence.

\subsection{Warning threshold for the Wenjia gully}

In order to improve the warning thresholds for forecasting the debris flow occurrence, which do not just represent a simple relationship between rainfall and debris flow occurrence, the pore pressure of landslide deposits was incorporated into the assessment of a threshold. Critical pore pressure for bedfailure-generating debris flows can be estimated with Eq. (2). The total unit weight of deposit material at the 1300 platform in the Wenjia gully is around $21 \pm 2 \mathrm{kN} \mathrm{m}^{-3}$, with an average slope inclination of $18.5^{\circ}$, and average effective friction angle is $27.5^{\circ}$ according to a consolidated undrained indoor test. Thus, the critical pore pressure of the deposited material can be calculated by Eq. (3).

$u_{\mathrm{c}}=(6.79-8.22) \times Z$

It is a linear function, as shown in Fig. 9. According to the real-time monitoring system, therefore, the critical pore pressure should be $6.79-8.22 \mathrm{kPa}$ at the depth of $1 \mathrm{~m}$ below the ground surface. According to Table 1, on 14 August 2012, there was a debris flow with run-off volume of $3.2 \times 10^{4} \mathrm{~m}^{3}$, and before the debris flow event pore pressure monitoring data show its maximum value was up to $9.1 \mathrm{kPa}$ (SY01), $7.8 \mathrm{kPa}$ (SY04), and $5.7 \mathrm{kPa}$ (SY03). As can be seen, SY01 has already exceeded the upper threshold of critical pore pressure $(8.22 \mathrm{kPa})$, which means that the critical pore pressure might be an important factor in debris flow occurrence.

Considering the acquired available data, the maximum hourly rainfall $\left(I_{\mathrm{h}}: \mathrm{mm}\right)$ and cumulative rainfall $\left(R_{\mathrm{t}}: \mathrm{mm}\right)$ are selected as the basic triggering rainfall parameters for the rainfall threshold, and the critical pore pressure $\left(u_{\mathrm{c}}\right)$ has been defined as a supporting factor in forecasting debris flow occurrence. For each rainfall event with or without debris flow occurrence, $R_{\mathrm{t}}$ (cumulative rainfall) and $I_{\mathrm{h}}$ (hourly intensity) can be plotted in an $X-Y$ field, like the debris flow event on 13 August 2010 (Fig. 10 Tag A). The red line is drawn under the lowest rectangle points, which represent debris flow occurrences under such rainfall conditions. The area between the line and the $x$ and $y$ axes defines combinations of $R_{\mathrm{t}}$ and $I_{\mathrm{h}}$ with a zero probability of debris flow occurrence. The gradient is an uncertain parameter which can be determined by expert experience and historical data sets (Huang et al., 2015b). Then, the rainfall threshold can be defined by Eq. (4) in Fig. 10 (Tag C).

$R_{\mathrm{t}}+2.4 I_{\mathrm{h}}=120$,

where $R_{\mathrm{t}}$ is the cumulative rainfall $(\mathrm{mm})$, and $I_{\mathrm{h}}$ is the maximum hourly rainfall (mm).

Above the red line, the probability of debris flow occurrence is higher. But among these points, there are eight rectangular points with debris flow. The possibility of debris flow occurrence can be predicted correctly up to $62 \%$ by rainfall threshold, which seems to be fine as a preliminary assessment. If the pore pressure monitoring data have been considered, in Fig. 10, there are three blue circular points without debris flow, but two magenta points show debris flow happened. The difference between them is that maximum pore pressure has exceeded the critical pore pressure line $(8.22 \mathrm{kPa})$. Therefore, the rainfall threshold and pore pressure threshold need to be combined while forecasting debris 


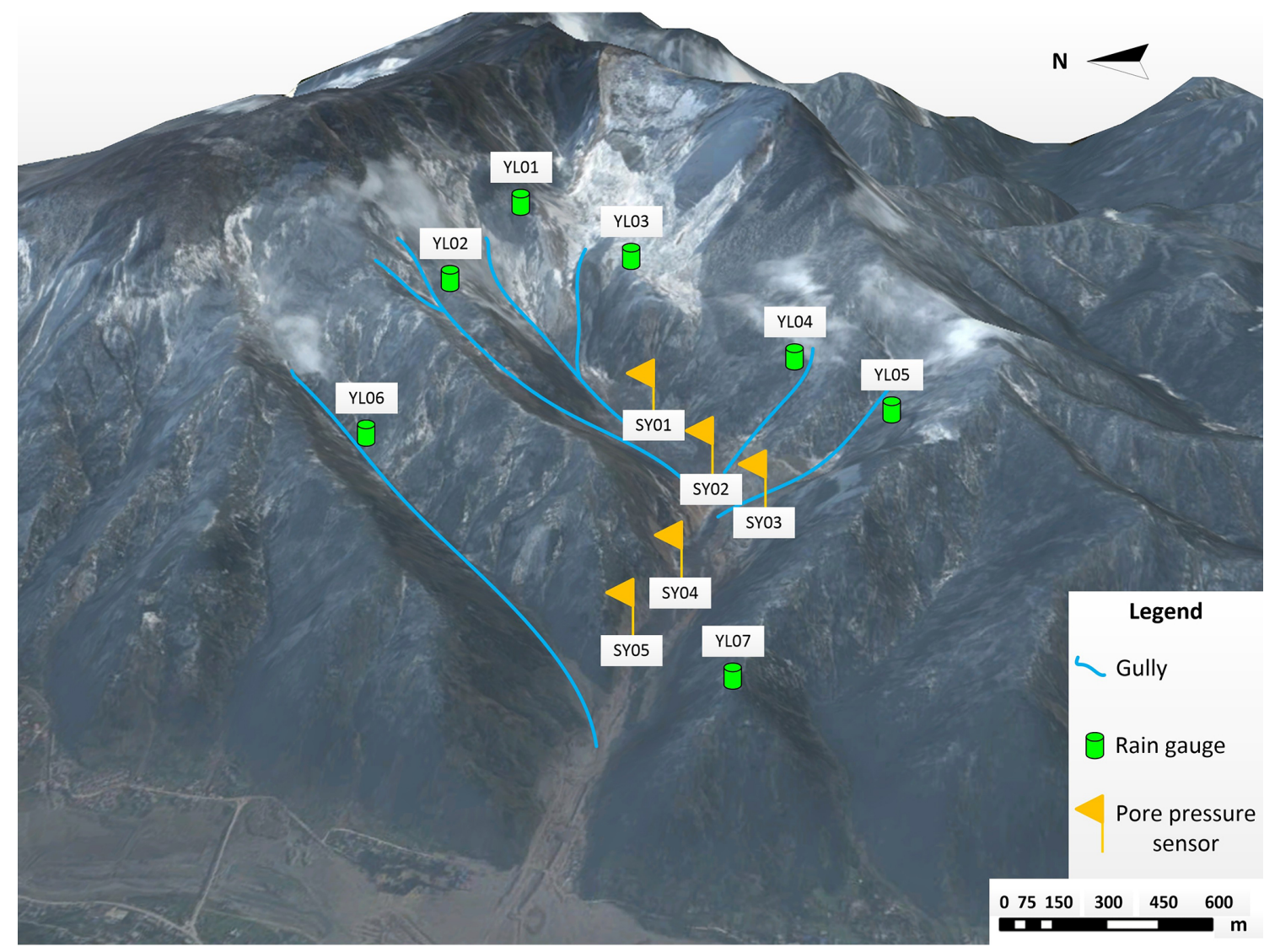

Figure 6. Layout map of the monitoring devices installed in the Wenjia gully (the base map is from Google Earth, the date of the background image is 18 December 2010).

Table 2. List of monitoring devices in the Wenjia gully.

\begin{tabular}{lllrr}
\hline No. & Longitude & Latitude & Elevation $(\mathrm{m})$ & Photo \\
\hline YL01 & $104^{\circ} 8^{\prime} 21^{\prime \prime} \mathrm{E}$ & $31^{\circ} 33^{\prime} 32^{\prime \prime} \mathrm{N}$ & 1652 & \\
YL02 & $104^{\circ} 7^{\prime} 55^{\prime \prime} \mathrm{E}$ & $31^{\circ} 33^{\prime} 11^{\prime \prime} \mathrm{N}$ & 1390 \\
YL03 & $104^{\circ} 8^{\prime} 39^{\prime \prime} \mathrm{E}$ & $31^{\circ} 33^{\prime} 14^{\prime \prime} \mathrm{N}$ & 1671 & \\
YL04 & $104^{\circ} 8^{\prime} 16^{\prime \prime} \mathrm{E}$ & $31^{\circ} 32^{\prime} 47^{\prime \prime} \mathrm{N}$ & 1490 & \\
YL05 & $104^{\circ} 7^{\prime} 47^{\prime \prime} \mathrm{E}$ & $31^{\circ} 32^{\prime} 39^{\prime \prime} \mathrm{N}$ & 1433 & \\
YL06 & $104^{\circ} 7^{\prime} 46^{\prime \prime} \mathrm{E}$ & $31^{\circ} 33^{\prime} 29^{\prime \prime} \mathrm{N}$ & 1280 & \\
YL07 & $104^{\circ} 7^{\prime} 9^{\prime \prime} \mathrm{E}$ & $31^{\circ} 32^{\prime} 59^{\prime \prime} \mathrm{N}$ & 1025 & \\
\hline SY01 & $104^{\circ} 8^{\prime} 12^{\prime \prime} \mathrm{E}$ & $31^{\circ} 33^{\prime} 9^{\prime \prime} \mathrm{N}$ & 1210 & \\
SY02 & $104^{\circ} 8^{\prime} 11^{\prime \prime} \mathrm{E}$ & $31^{\circ} 33^{\prime} 9^{\prime \prime} \mathrm{N}$ & 1212 & \\
SY03 & $104^{\circ} 8^{\prime} 11^{\prime \prime} \mathrm{E}$ & $31^{\circ} 33^{\prime} 8^{\prime \prime} \mathrm{N}$ & 1208 & \\
SY04 & $104^{\circ} 7^{\prime} 49^{\prime \prime} \mathrm{E}$ & $31^{\circ} 32^{\prime} 55^{\prime \prime} \mathrm{N}$ & 1092 & \\
SY05 & $104^{\circ} 7^{\prime} 48^{\prime \prime} \mathrm{E}$ & $31^{\circ} 32^{\prime} 56^{\prime \prime} \mathrm{N}$ & 1081 & \\
\hline
\end{tabular}

flow occurrence; then there must be a much higher possibility of successful prediction. For a given rainfall event, the starting point and its trend can be calculated and plotted in Fig. 10 in order to verify in real time whether the trend line exceeds the warning threshold. More detailed information will be discussed with an example as follows.

\subsection{Example of application}

In order to make better use of the presented method, early warning criteria have to be simplified to make a clear understanding for the study area. Therefore, a three-level early warning system has been proposed for the Wenjia gully, as shown in Table 3. At level one there is a low possibility of de- 


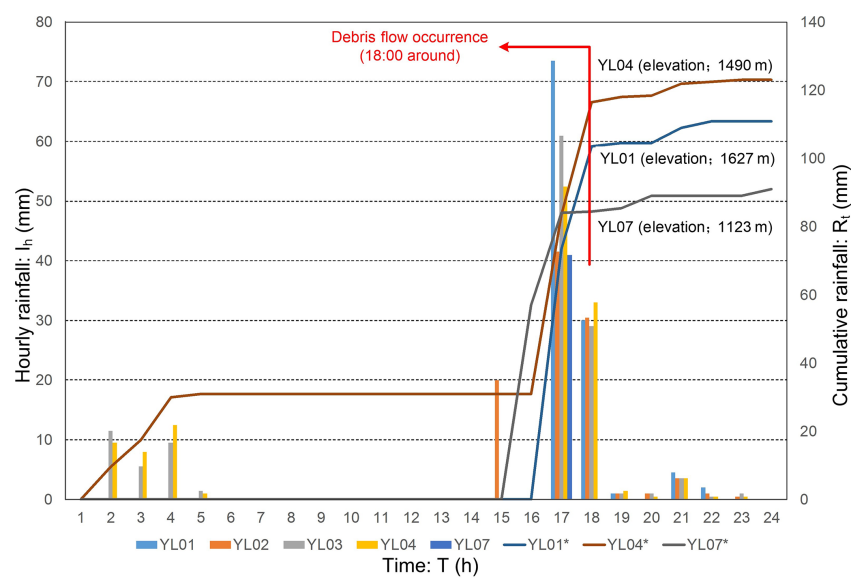

Figure 7. The rainfall in Wenjia gully on 14 August 2012 (the column graphs are hourly rainfall and the single line curves are cumulative rainfall).

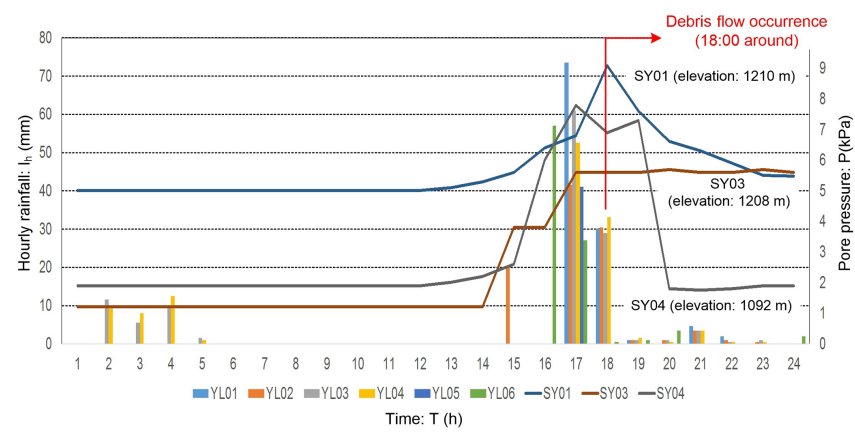

Figure 8. The rainfall and pore pressure in Wenjia gully on $14 \mathrm{Au}-$ gust 2012 (the column graphs are hourly rainfall and the single line curves are pore pressure).

bris flow occurrence. At level two there is a chance of debris flow occurrence in the near future, and warning messages need to be sent to local authorities and countermeasures need to be discussed. At level three debris flow is very likely to occur immediately; therefore, local residents need to be alerted and prevented from entering threatened areas.

In order to explain how the presented method can be used in a real-time debris flow early warning, the rainfall on 8 July 2013 has been selected as an application (Fig. 11). The small, circular, solid magenta points connected by a magenta line shows the course of the real-time monitored data during this rainstorm, with the cumulative rainfall on the $X$ axis and hourly rainfall intensity on the $Y$ axis. The inset $\mathrm{A}$ in Fig. 11 shows the rainfall data at 17:00 on 8 July 2013, with a pore pressure of $3.00 \mathrm{kPa}$ at that time. A total of $3 \mathrm{~h}$ later at 20:00 (inset B), the real-time rainfall has exceeded the rainfall threshold, but the pore pressure did not exceed the critical pore pressure $(6.3 \mathrm{kPa}<6.79$ or $8.22 \mathrm{kPa})$, indicating that the warning information stayed in the attention level. About $1 \mathrm{~h}$ later at 21:00 (inset C), the pore pressure did exceed the lower

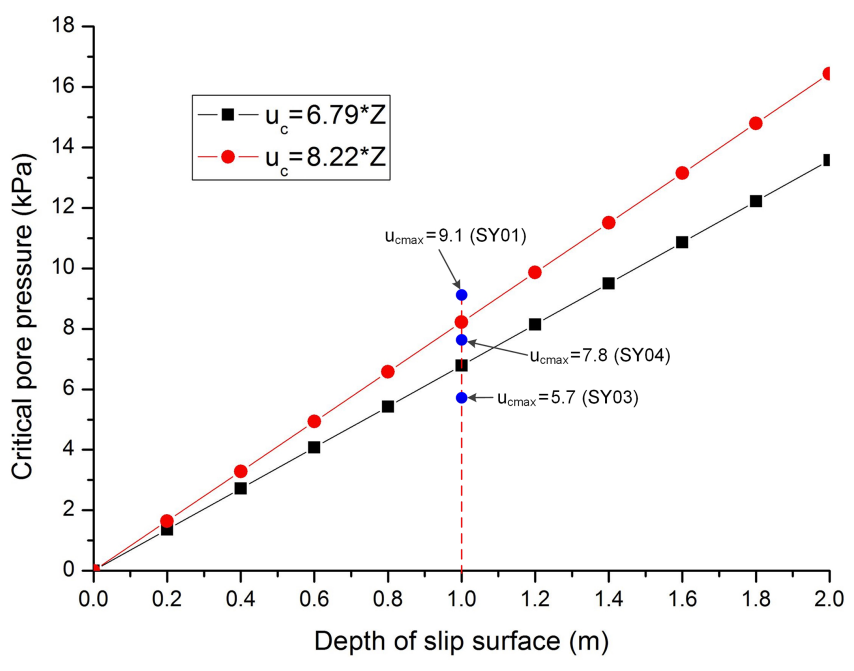

Figure 9. The critical pore pressure with probable depth of slip surface in the Wenjia gully.

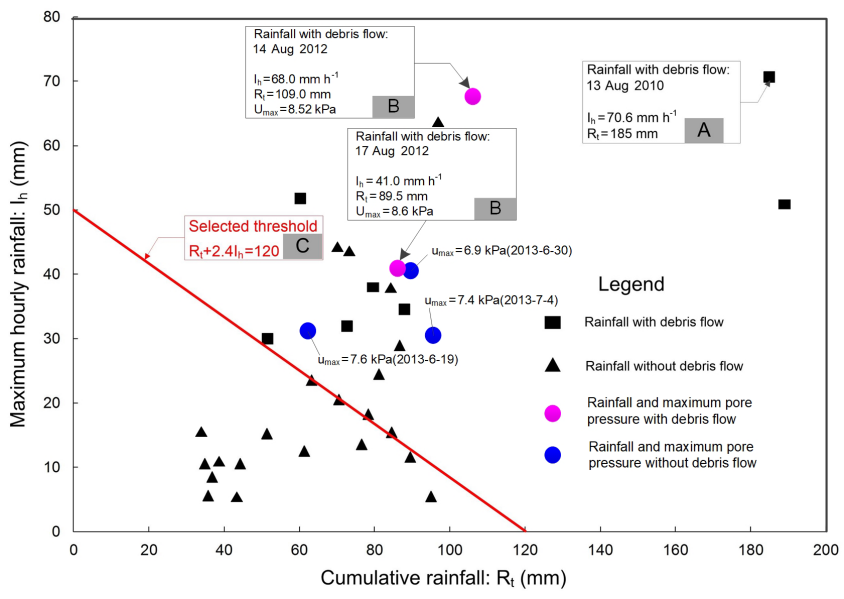

Figure 10. Warning threshold combined with rainfall and pore pressure.

critical pore pressure $(7.8 \mathrm{kPa}>6.79 \mathrm{kPa})$, indicating that debris flow had a much higher possibility of occurring. Further, the pore pressure increased to $8.7 \mathrm{kPa}$ over the upper critical pore pressure $(8.22 \mathrm{kPa})$, and finally triggered a debris flow occurrence (inset D).

The case study shows how to use this presented combined warning threshold in a real-time way during a rainstorm. In 2014, two heavy rainstorms (Table 1) both exceeded the rainfall threshold, but pore pressure did not cross the critical pore pressure during the whole course of the rainfall. Therefore, a warning message has been sent to the local government with a median possibility of debris flow occurrence. At last, fortunately no debris flow occurred during these rainstorms. Therefore, the presented comprehensive warning threshold can be used as a helpful tool for debris flow prediction 
Table 3. Recommended warning levels for Wenjia gully.

\begin{tabular}{lll}
\hline Warning & Trigger & Response \\
level & & \\
\hline Zero & $\begin{array}{l}\text { Default level. } \\
\text { Not exceeding rainfall } \\
\text { threshold or critical } \\
\text { pore pressure. }\end{array}$ & $\begin{array}{l}\text { Null: but data are } \\
\text { checked daily. Weekly } \\
\text { monitoring bulletin. }\end{array}$ \\
\hline Attention & $\begin{array}{l}\text { Attention level. } \\
\text { Exceeding rainfall } \\
\text { threshold but not } \\
\text { critical pore pressure. }\end{array}$ & $\begin{array}{l}\text { Watch: data are } \\
\text { checked more fre- } \\
\text { quently. Daily monitor- } \\
\text { ing bulletin. Authorities } \\
\text { and experts are alerted. } \\
\text { Preparing for alarm. }\end{array}$ \\
\hline Warning & $\begin{array}{l}\text { Alert level. } \\
\text { Exceeding both rainfall } \\
\text { threshold and critical } \\
\text { pore pressure. }\end{array}$ & $\begin{array}{l}\text { Warning: data are } \\
\text { checked even more } \\
\text { frequently. Two mon- } \\
\text { itoring bulletins per } \\
\text { day. Local people are } \\
\text { alerted. }\end{array}$ \\
\hline
\end{tabular}

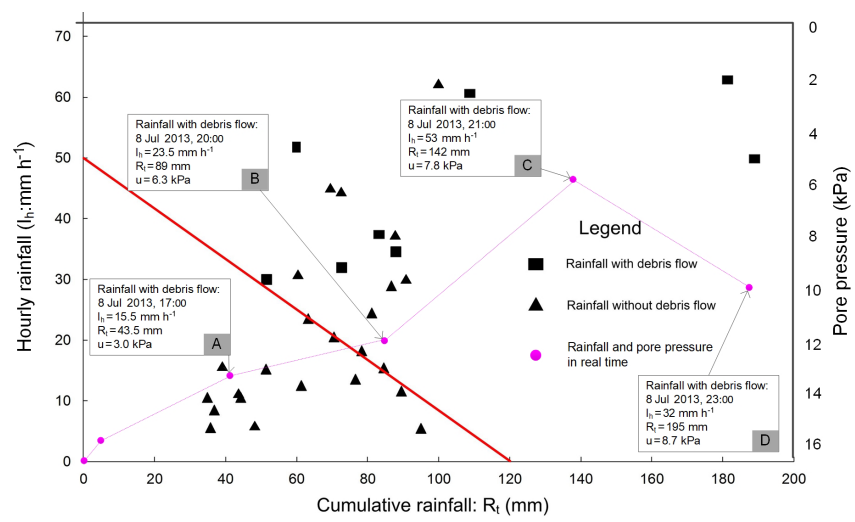

Figure 11. Case application of the presented method in Wenjia gully (8 July 2013).

in mountainous areas, especially in this earthquake area of southwest China where a lot of loose material is available.

\section{Discussion and conclusion}

Gully-type debris flow, usually triggered by high-intensity and short-duration rainstorms, causes serious harm to human lives and property every year in the mountainous region of southwest China. Therefore, in order to prevent such natural disasters, there is an urgent requirement for an effective method to predict debris flow occurrence. The combined warning threshold proposed and discussed in this paper not only uses the common rainfall threshold, but also includes the critical pore pressure determined by a hydromechanical stability model.
Two rainfall triggering factors, maximum hourly rainfall and cumulative rainfall, have been selected to establish a simple rainfall threshold as a baseline for debris flow early warning. Critical pore pressure can be used as a combined threshold to make the warning threshold better in practical usage. The Wenjia gully was selected as a case study for a detailed explanation of the presented method, for the great volume of deposited materials triggered by Wenchuan earthquake along the channel. The results show that the combined threshold can play a great role in debris flow prediction, at least reducing the mistaken alerts for debris flow occurrence compared to use of only a rainfall threshold. However, such a combined warning threshold still has some restrictions. First, the critical pore pressure is a linear function with the depth of a potential slip surface, which is difficult to determine in an actual gully by the real-time monitoring system. In this study, $1 \mathrm{~m}$ depth of the slip surface was selected as a possible condition for this preliminary study. Second, the study area still focused on the Wenjia gully; therefore the presented method cannot be used in other gullies directly. But in the near future, different gully-type debris flows will be researched, and more subsequent work needs to be carried out for a better understanding of debris flow prediction. Finally, the most complex problem is the final determination of whether to alert the local population, and whether action needs to be taken immediately or later. Debris flow early warning is not an imminent hazard but is just regarded as a potential danger. In spite of these limitations, the methodology presented in this paper has reached the goal of establishing a preliminary combined warning threshold for gully-type debris flow prediction. In future studies, the critical pore pressure threshold, which is dependent on topography, geology, and soil properties, can be determined by long-term field monitoring and more important by debris flow tests in a laboratory with different slope angles and depths of slip surface to reduce the loss of property and lives.

Data availability. All data included in this study are available upon request by contacting the corresponding author.

Author contributions. JH conducted the analysis and wrote the paper, TWJvA helped with the language, and CW \& QL helped with the data analysis.

Competing interests. The authors declare that they have no conflict of interest.

Special issue statement. This article is part of the special issue "Flood risk assessment and management". It is a result of the EGU General Assembly 2018, Vienna, Austria, 8-13 April 2018. 
Acknowledgements. This study was financially supported by the Funds for Creative Research Groups of China (grant no. 41521002), International Cooperation (NSFC-RCUK_NERC), Resilience to Earthquake-induced landslide risk in China (grant no. 41661134010), and State Key Laboratory of Geo-hazard Prevention and Geo-environment Protection (Chengdu University of Technology) (grant no. SKLGP2017Z006). The authors also give sincere thanks to Niek Rengers for his review of an earlier version of this paper and for his suggestions to polish the language, which greatly improved the quality of the paper.

Edited by: Dhruvesh Patel

Reviewed by: Qiang Dai

\section{References}

Baum, R. L. and Godt, J. W.: Early warning of rainfall-induced shallow landslides and debris flows in the USA, Landslides, 7, 259272, 10.1007/s10346-009-0177-0, 2009.

Beven, K. J. and Kirkby, M. J.: A physically based, variable contributing area model of basin hydrology/Un modèle à base physique de zone d'appel variable de l'hydrologie du bassin versant, Hydrol. Sci. B., 24, 43-69, https://doi.org/10.1080/02626667909491834, 1979.

Cannon, S. H., Gartner, J. E., Wilson, R. C., Bowers, J. C., and Laber, J. L.: Storm rainfall conditions for floods and debris flows from recently burned areas in southwestern Colorado and southern California, Geomorphology, 96, 250-269, https://doi.org/10.1016/j.geomorph.2007.03.019, 2008.

Chae, B.-G. and Kim, M.-I.: Suggestion of a method for landslide early warning using the change in the volumetric water content gradient due to rainfall infiltration, Environ. Earth Sci., 66, 19731986, https://doi.org/10.1007/s12665-011-1423-z, 2011.

Deb, S. K. and El-Kadi, A. I.: Susceptibility assessment of shallow landslides on Oahu, Hawaii, under extreme-rainfall events, Geomorphology, 108, 219-233, 2009.

Glade, T., Crozier, M., and Smith, P.: Applying probability determination to refine landslide-triggering rainfall thresholds using an empirical “Antecedent Daily Rainfall Model”, Pure Appl. Geophys., 157, 1059-1079, 2000.

Guo, X.-j., Cui, P., and Li, Y.: Debris flow warning threshold based on antecedent rainfall: A case study in Jiangjia Ravine, Yunnan, China, J. Mt. Sci., 10, 305-314, https://doi.org/10.1007/s11629013-2521-z, 2013.

Guzzetti, F., Peruccacci, S., Rossi, M., and Stark, C. P.: Rainfall thresholds for the initiation of landslides in central and southern Europe, Meteorol. Atmos. Phys., 98, 239-267, https://doi.org/10.1007/s00703-007-0262-7, 2007a.

Guzzetti, F., Peruccacci, S., Rossi, M., and Stark, C. P.: The rainfall intensity-duration control of shallow landslides and debris flows: an update, Landslides, 5, 3-17, https://doi.org/10.1007/s10346007-0112-1, 2007b.

Huang, J., Huang, R., Ju, N., Xu, Q., and He, C.: 3D WebGIS-based platform for debris flow early warning: A case study, Eng. Geol., 197, 57-66, https://doi.org/10.1016/j.enggeo.2015.08.013, 2015a.

Huang, J., Ju, N. P., Liao, Y. J., and Liu, D. D.: Determination of rainfall thresholds for shallow landslides by a probabilistic and empirical method, Nat. Hazards Earth Syst. Sci., 15, 2715-2723, https://doi.org/10.5194/nhess-15-2715-2015, 2015 b.

Huang, R., Huang, J., Ju, N., He, C., and Li, W.: WebGIS-based information management system for landslides triggered by Wenchuan earthquake, Nat. Hazards, 65, 1507-1517, 2013.

Iverson, R. M.: The physics of debris flows, Rev. Geophys., 35, 245-296, 1997.

Kean, J. W., McCoy, S. W., Tucker, G. E., Staley, D. M., and Coe, J. A.: Runoff-generated debris flows: Observations and modeling of surge initiation, magnitude, and frequency, J. Geophys. Res.-Earth, 118, 2190-2207, https://doi.org/10.1002/jgrf.20148, 2013.

Keefer, D. K., Wilson, R. C., Mark, R. K., Brabb, E. E., M.Brown, W., Ellen, S. D., Harp, E. L., Wieczorek, G. F., Alger, C. S., and Zatkin, R. S.: Real-Time Landslide Warning during Heavy Rainfall, Science, 238, 921-925, 1987.

Michel, G. P. and Kobiyama M.: Landslides and Engineered Slopes. Experience, Theory and Practice, edited by: Aversa, S., Cascini, L., Picarelli, L., and Scavia, C., 1417-1421, 2016.

Peng, J., Fan, Z., Wu, D., Zhuang, J., Dai, F., Chen, W., and Zhao, C.: Heavy rainfall triggered loess-mudstone landslide and subsequent debris flow in Tianshui, China, Eng. Geol., 186, 79-90, https://doi.org/10.1016/j.enggeo.2014.08.015, 2014.

Segoni, S., Rosi, A., Rossi, G., Catani, F., and Casagli, N.: Analysing the relationship between rainfalls and landslides to define a mosaic of triggering thresholds for regional-scale warning systems, Nat. Hazards Earth Syst. Sci., 14, 2637-2648, https://doi.org/10.5194/nhess-14-2637-2014, 2014.

Shieh, C.-L., Chen, Y., Tsai, Y., and Wu, J.: Variability in rainfall threshold for debris flow after the Chi-Chi earthquake in central Taiwan, China, Int. J. Sediment Res., 24, 177-188, 2009.

Shuin, Y., Hotta, N., Suzuki, M., and Ogawa, K.-i.: Estimating the effects of heavy rainfall conditions on shallow landslides using a distributed landslide conceptual model, Phys. Chem. Earth Pt. A/B/C, 49, 44-51, https://doi.org/10.1016/j.pce.2011.06.002, 2012.

Thiebes, B.: Landslide analysis and early warning systems: local and regional case study in the Swabian Alb, Germany, Springer Science \& Business Media, 2012.

Tropeano, D. and Turconi, L.: Using historical documents for landslide, debris flow and stream flood prevention. Applications in Northern Italy, Nat. Hazards, 31, 663-679, 2004.

van Asch, T. W. J., Tang, C., Alkema, D., Zhu, J., and Zhou, W.: An integrated model to assess critical rainfall thresholds for run-out distances of debris flows, Nat. Hazards, 70, 299-311, https://doi.org/10.1007/s11069-013-0810-z, 2013.

$\mathrm{Xu}, \mathrm{Q} .:$ The 13 August 2010 catastrophic debris flows in Sichuan Province: characteristics, geneticmechanism and suggestions, J. Eng. Geol., 18, 596-608, 2010.

Yin, Y., Wang, H., Gao, Y., and Li, X.: Real-time monitoring and early warning of landslides at relocated Wushan Town, the Three Gorges Reservoir, China, Landslides, 7, 339-349, https://doi.org/10.1007/s10346-010-0220-1, 2010.

Yu, B., Li, L., Wu, Y., and Chu, S.: A formation model for debris flows in the Chenyulan River Watershed, Taiwan, Nat. Hazards, 68, 745-762, https://doi.org/10.1007/s11069-013-0646-6, 2013a. 
Yu, B., Ma, Y., and Wu, Y.: Case study of a giant debris flow in the Wenjia Gully, Sichuan Province, China, Nat. Hazards, 65, 835849, https://doi.org/10.1007/s11069-012-0395-y, 2013b.

Yu, B., Zhu, Y., Wang, T., Chen, Y., Zhu, Y., Tie, Y., and Lu, K.: A prediction model for debris flows triggered by a runoff-induced mechanism, Nat. Hazards, 74, 1141-1161, 2014.
Zhou, W. and Tang, C.: Rainfall thresholds for debris flow initiation in the Wenchuan earthquake-stricken area, southwestern China, Landslides, 11, 877-887, https://doi.org/10.1007/s10346013-0421-5, 2013. 